\title{
Comparative Study of Rectal Misoprostol to Oxytocin Infusion in Preventing Postpartum Haemorrhage After Caesarean Section
}

\author{
Adanikin AI, ${ }^{1}$ Orji E, ${ }^{1}$ Adanikin PO, ${ }^{2}$ Olaniyan $\mathrm{O}^{1}$ \\ ${ }^{1}$ Department of Obstetrics and Gynaecology, Obafemi Awolowo University Teaching Hospitals Complex, Ile- \\ Ife, Nigeria \\ ${ }^{2}$ Health Centre, Obafemi Awolowo University, Ile-Ife, Nigeria.
}

\begin{abstract}
Aims: This comparative study aimed to compare the efficacy of rectal misoprostol to oxytocin infusion in preventing primary postpartum haemorrhage after caesarean section.

Methods: Fifty pregnant women with identifiable risk factors for post-partum haemorrhage who delivered baby by caesarean section were randomized to receive $600 \mu \mathrm{g}$ rectal misoprostol and a placebo infusion intravenously or placebo rectally and a $20 \mathrm{iu}$ oxytocin infusion. Post-operative blood loss four hours after surgery was estimated by application of pads of known weight.
\end{abstract}

Results: The mean immediate four hours post-operative blood loss was not significantly different between the rectal misoprostol and oxytocin infusion group $(100.08 \pm 24.85 \mathrm{ml}$ versus $108.20 \pm 29.93 \mathrm{ml} ; \mathrm{p}=0.144)$ and the change between the pre-operative and post-operative hematocrit was similar.

Conclusions: Post-caesarean section rectal misoprostol has comparative efficacy to oxytocin infusion in preventing post-partum haemorrhage. It is recommended for use as alternative uterotonic in settings where there is low refrigeration capacity.

Keywords: caesarean section, misoprostol, oxytocin infusion, postpartum haemorrhage.

\section{INTRODUCTION}

Misoprostol is a synthetic prostaglandin $\mathrm{E}_{1}$ analogue originally marketed for treatment/prevention of nonsteroidal anti-inflammatory drug-induced peptic ulcer. ${ }^{1}$ However, due to its uterotonic properties, it has gained wide use for labour induction ${ }^{2,3}$ and induction of abortion. ${ }^{4,5}$

Over the years, there has been expanding interest in the use of misoprostol toprevent and manage postpartum haemorrhage. ${ }^{6-8}$ With the World Health Organization (WHO) enlisting it as essential medicine for primary postpartum hemorrhage (PPH) in 2011, ${ }^{9}$ body of research is growing on the effectiveness and safety for this purpose.

\section{CORRESPONDENCE}

Dr Abiodun Idowu Adanikin

Department of Obstetrics and Gynaecology,

Obafemi Awolowo University Teaching Hospital, Ile-Ife, Osun State, Nigeria.

Email: adanikinbiodun@yahoo.com

Phone: +2348034252126
After caesarean section, uterotonic in form of oxytocin infusion (20-40 iu) or rectal misoprostol (200-600 $\mu \mathrm{g}$ ) is administered to contract the uterus for the succeeding 4-6 hours post-surgery in patients at risk of PPH. ${ }^{10-12}$ Although this practise is popular in our environment, objective comparative assessment of both measures is lacking; this study therefore made the comparison.

\section{METHODS}

This study was conducted at the Obafemi Awolowo University Teaching Hospital, Ile-Ife, Nigeria between August 1 and October 31, 2011. The Ethics Review Committee of the hospital approved the study

The papers in this journal are published under the terms of the Creative Commons Attribution License. Users are allowed to read, download, copy, distribute, print, search, or link to the full texts of the articles in this journal without asking prior permission from the publisher or the author. 
protocol. The primary outcome variable of the study was four-hour post-operative blood loss.

\section{Sample size}

In a study by Owonikoko et $\mathrm{al}^{13}$ comparing sublingual misoprostol with oxytocin infusion in reducing blood loss after caesarean section, they reported a mean 4 hour post-operative blood loss of $58.2 \pm 20.7 \mathrm{ml}$ for the misoprostol group and $80.5 \pm 26.8 \mathrm{ml}$ for the oxytocin infusion group. These data were used to calculate the study sample size via a formula derived by Kirkwood and Steme. ${ }^{14}$ Sample size of 50 (25 in each group) would have $90 \%$ power to detect a clinically important difference of $20.7 \mathrm{ml}$ for the misoprostol group versus $26.8 \mathrm{ml}$ for the oxytocin infusion group as observed by Owonikoko et al. ${ }^{13}$

Fifty women who were scheduled to undergo caesarean section with identifiable risk factors for primary postpartum haemorrhage such as prolonged labour, obstructed labour, grand-multiparity, multiple gestations, polyhydraminous were enrolled for the study after written informed consent. Asthmatics or patients with hypersensitivity to prostaglandins were excluded.

\section{Study procedure}

By $1: 1 \quad$ computer-generated randomization, participants were assigned to their group while the pharmacy department provided the study drugs and placebos in unidentifiable form. The numbered medications contained $600 \mu \mathrm{g}$ tablets of misoprostol to be used rectally plus a pre-filled syringe with normal saline solution, or identical placebo tablets to be used rectally plus a pre-filled syringe with 20 iu of oxytocin. A resident doctor was responsible for the patient's allocation according to randomisation table. The patients and the outcome assessor were blinded to the study medications. In accordance to the randomisation, after cord clamping participants received either $600 \mu \mathrm{g}$ of rectal misoprostol plus an infusion of $500 \mathrm{ml}$ of $5 \%$ dextrose saline solution supplemented with placebo over 4 hours, or a rectal placebo plus an infusion of $500 \mathrm{ml}$ of $5 \%$ dextrose saline solution supplemented with 20 iu of oxytocin over four hours. Additional administration of uterotonics was allowed in cases of bleeding in excess of $500 \mathrm{ml}$ within the four-hour period, but no patient needed it.

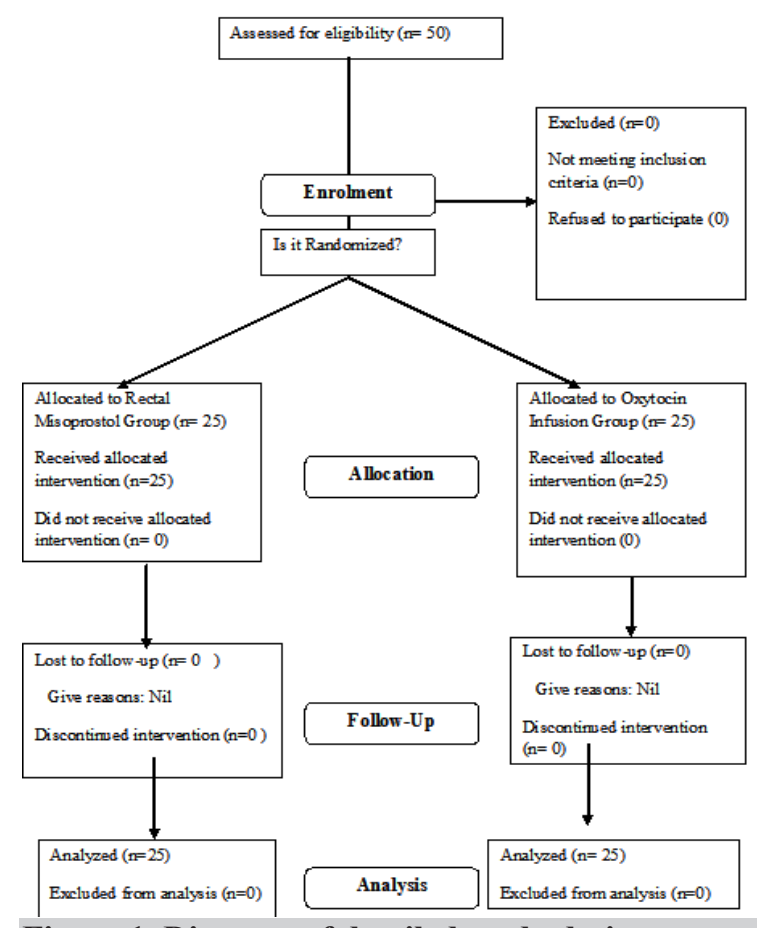

Figure 1. Diagram of detailed study design.

\section{Calculation of blood loss}

Immediate blood loss up till four hours post-partum was measured by the application of pads of known weight to the perineum. These pads were weighed four hours post-partum, and the blood loss estimated from the pads' weight gain as: $1 \mathrm{~g} \approx 1 \mathrm{ml} .^{15,16}$ The instrument used to weigh the pads was a MettlerPB153 weighing scale, which had a sensitivity of $0.001 \mathrm{gm}$. The scale was calibrated prior to weighing as well as during weighing of large numbers of products. The instrument was evaluated as stable; inter-weigher reliability was 0.98 . The used pads were weighed in triplicate and the mean of the three weights were entered into the database. Haematocrit was checked before and two days after surgery.

\section{Statistical analysis}

Data were analyzed using the computer soft ware SPSS version 15. Frequency tables were generated. Association between continuous variables was tested using the student t-test while Chi square or Fisher's exact test was used to test association between categorical variables. Level of significance $(\alpha)$ was set at 0.05 .

\section{RESULTS}

Fifty women who met the inclusion criteria were enrolled and randomized into either misoprostol or oxytocin infusion group (Figure 1). 
Table 1. Baseline characteristics of participants $(n=50)$.

\begin{tabular}{|c|c|c|c|c|c|}
\hline Variables & $\begin{array}{l}\text { Misoprostol } \\
\text { group } \\
(n=25)\end{array}$ & $\begin{array}{l}\text { Oxytocin group } \\
(n=25)\end{array}$ & Odd ratio & $\begin{array}{l}95 \% \\
\text { Confidence }\end{array}$ & P-value \\
\hline Age (years) & $30.6 \pm 6.33$ & $30.84 \pm 5.69$ & & & 0.671 \\
\hline GA (weeks) & $39.03 \pm 1.62$ & $39.07 \pm 1.26$ & & & 0.853 \\
\hline Parity & $1.88 \pm 1.42$ & $1.76 \pm 1.09$ & & & 0.726 \\
\hline \multicolumn{6}{|l|}{ Indications for $\mathrm{C} / \mathrm{S}, \mathbf{n}(\%)$ : } \\
\hline Prolonged labour & $8(32)$ & $7(28)$ & 1.00 & & \\
\hline Obstructed labour & $1(4)$ & $4(8)$ & 4.57 & $0.51-40.90$ & 0.194 \\
\hline Multiple pregnancy & $4(16)$ & $2(8)$ & 0.57 & $0.09-3.57$ & 0.577 \\
\hline Grand multiparity & $4(16)$ & $2(8)$ & 0.57 & $0.09-3.57$ & 0.577 \\
\hline Fetal macrosomia & $5(20)$ & $3(12)$ & 0.69 & $0.13-3.60$ & 0.673 \\
\hline Failed Induction & $2(8)$ & $4(16)$ & 2.29 & $0.37-14.30$ & 0.407 \\
\hline Others & $1(4)$ & $3(12)$ & 3.43 & $0.38-30.68$ & 0.313 \\
\hline \multicolumn{6}{|l|}{ Type of Anaesthesia, n (\%): } \\
\hline Spinal & $20(80)$ & $22(88)$ & 1.00 & & \\
\hline General & $5(20)$ & $3(12)$ & 0.55 & $0.13-2.36$ & 0.440 \\
\hline Duration of surgery (mins) & $54.72 \pm 9.51$ & $54.80 \pm 8.77$ & & & 0.974 \\
\hline
\end{tabular}

Data presented as: mean \pm standard deviation; $\mathrm{n}(\%)$.

$\mathrm{C} / \mathrm{S}$ : Caesarean section.

Table 1 shows that the participants in both groups did not differ significantly in mean age, gestational age at delivery, parity, indication for caesarean section, type of anaesthesia and mean duration of surgery.

Table 2. Operative outcome in both groups $(n=50)$.

\begin{tabular}{llll}
\hline Variables & $\begin{array}{l}\text { Misoprostol } \\
\text { group }\end{array}$ & $\begin{array}{l}\text { Oxytocin } \\
\text { infusion }\end{array}$ & P-value \\
\hline $\begin{array}{l}\text { Pre-operative } \\
\text { hematocrit (\%) }\end{array}$ & $34.68 \pm 3.67$ & $34.24 \pm$ & 0.577 \\
$\begin{array}{l}\text { Post operative } \\
\text { hematocrit (\%) }\end{array}$ & $33.12 \pm 3.77$ & $32.52 \pm$ & 0.436 \\
$\begin{array}{l}\text { 4 hours post } \\
\text { operative EBL }\end{array}$ & $100.8 \pm 24.8$ & $108.20 \pm$ & 0.144 \\
(mive & & 29.93 &
\end{tabular}

(ml)

\section{Side effects:}

\begin{tabular}{llcl} 
Shivering, $\mathrm{n}(\%)$ & $1(4)$ & $2(8)$ & $>0.999$ \\
Pyrexia, $\mathrm{n}(\%)$ & $4(16)$ & $2(8)$ & 0.667 \\
Nausea, $\mathrm{n}(\%)$ & $2(8)$ & $1(4)$ & $>0.999$ \\
Vomiting, $\mathrm{n}(\%)$ & $2(8)$ & $2(8)$ & $>0.999$ \\
\hline Data presented as: mean \pm standard deviation; & $n \quad(\%)$. \\
Abbreviations: EBL, estimated blood loss.
\end{tabular}

From Table 2, the studied groups had no significant difference in pre-operative and post-operative hematocrit. The mean four hours post-operative blood loss was also not significantly different in the two groups $(100.08 \pm 24.85 \mathrm{ml}$ versus $108.20 \pm 29.93$ $\mathrm{ml} ; \mathrm{p}=0.144)$.
There was no difference in occurrence of shivering ( $\mathrm{p}$ $=0.999)$, pyrexia $(\mathrm{P}=0.667)$, nausea $(\mathrm{p}=0.999)$ and vomiting $(\mathrm{p}=0.999)$.

\section{DISCUSSION}

The mean immediate four hours post-operative blood loss was not significantly different in the two groups studied. No patient had bleeding in excess of 500 $\mathrm{ml}$ to warrant additional uterotonic. This outcome indicated the efficacy of both drugs in preventing PPH. The finding is in synchrony with earlier conclusion by Nasr et $\mathrm{al}^{6}$ that rectal misoprostol was effective in reducing blood loss after delivery. Lapaire et $\mathrm{al}^{17}$ who compared oral misoprostol with oxytocin infusion post-caesarean section and found similar efficacy of both drugs, though misoprostol had higher side effects profile. Also, Owinikoko et $\mathrm{al}^{13}$ found comparative efficacy of sublingual misoprostol to oxytocin infusion after caesarean section but with significant misoprostol side effect.

Side effect of misoprostol was not prominent in this study. Rectal misoprostol is known to have a steady serum rise with lower peak serum concentration and longer half life. ${ }^{18,19}$ This may account for the low side effect profile. The longer half-life of rectally administered misoprostol equally has a beneficial effect of prolonging uterine contraction and preventing a delayed haemorrhage. ${ }^{19,20}$

Post-surgery, other routes of administration of 
misoprostol may not be favoured. There is likelihood that the surgeon may want patient to avoid immediate oral intake while lochia flow after delivery may wash away vaginal misoprostol. Rectal administration is therefore an appropriate route. In tropical developing countries, tendency of oxytocin losing potency is high as proper refrigeration capability is low. Because of this, there are occasions where post-partum haemorrhage ensues despite the use of oxytocin. Misoprostol on the other hand, is stable in tropical climate while still maintaining its potency. ${ }^{21}$

\section{CONCLUSIONS}

This study showed that misoprostol was as effective as oxytocin infusion in preventing PPH. Misoprostol can serve as alternative to oxytocin in tropical climates with little capability for refrigeration for prevention of post-partum haemorrhage. Authors recommend further studies on this subject.

\section{REFERENCES}

1. Monk JP, Clissold SP. Misoprostol: a preliminary review of its pharmacodynamic and pharmacokinetic properties, and therapeutic efficacy in the treatment of peptic ulcer disease. Drugs. 1987;33:1-30.

2. Kulier R, Gulmezoglu AM, Hofmeyr GJ, Cheng LN, Campana A. Medical methods for first trimester abortion. Cochrane Database Syst Rev. 2004;(2):CD002855.

3. Fawole AO, Adegbola O, Adeyemi AS, Oladapo OT, Alao MO. Misoprostol for induction of labour: a survey of attitude and practice in southwestern Nigeria. Arch Gynecol Obstet. 2008; 278(4):353-8.

4. Neilson JP, Hickey M, Vazquez J. Medical treatment for early fetal death (less than 24 weeks). Cochrane Database Syst Rev. 2006;19(3):CD002253.

5. Menakaya U, Otoide V, Omo Aghoja L, Odunsi K, Okonofua F. Experience with misoprostol in the management of missed abortion in the second trimester. J Obstet Gynaecol. 2005;25(6):583-5.

6. Nasr A, Shahin AY, Elsamman AM, Zakherah MS, Shaaban OM. Rectal misoprostol versus intravenous oxytocin for prevention of postpartum hemorrhage. Int $\mathrm{J}$ Gynaecol Obstet. 2009;105(3):244-7.

7. Enakpene CA, Morhason-Bello IO, Enakpene EO, Arowojolu AO, Omigbodun AO. Oral misoprostol for the prevention of primary post-partum hemorrhage during third stage of labor. $\mathrm{J}$ Obstet Gynaecol Res. 2007;33(6):810-7.
8. Jadesimi A, Okonofua FE. Tackling the unacceptable: Nigeria approves misoprostol for postpartum haemorrhage.J Fam Plan Reprod Health Care. 2006;32(4):213-4.

9. World Health Organization. WHO Model Lists of Essential Medicines. 17th ed. [cited 30 March 2011]. Available from http:// www.who.int/medicines/publications/Essential medicines/en

10. Fekih M, Jnifene A, Fathallah K, Ben Regaya L, Memmi A, Bouguizene $\mathrm{S}$, et al. Benefit of misoprostol for prevention of post-partum hemorrhage in caesarean section: a randomized controlled trial. J Gynecol Obstet Biol Reprod. 2009;38(7):58893.

11. Eftekhari N, Doroodian M, Lashkarizadeh R. The effect of sublingual misoprostol versus intravenous oxytocin in reducing bleeding after caesarean section. J Obstet Gynaecol. 2009;29(7):633-6.

12. Murphy DJ, MacGregor H, Munishankar B, McLeod G. A randomised controlled trial of oxytocin 5IU and placebo infusion versus oxytocin 5IU and 30IU infusion for the control of blood loss at elective caesarean section. Eur J Obstet Gynecol Reprod Biol. 2009;142(1):30-3.

13. Owonikoko KM, Arowojolu AO, Okunlola MA. J Obstet Gynecol Res. 2011;37(7):715-21.

14. Kirkwood BR, Sterne JAC, editors. Essential medical statistics. 2nd ed. Massachusetts: Blackwell Science Ltd; 2003.

15. Mansfield PK, Voda A, Allison G. Validating a pencil-and-paper measure of perimenopausal menstrual blood loss. Womens Health Issues. 2004;14:242-7.

16. Schorn MN. Measurement of blood loss: review of the literature. J Midwifery Womens Health. 2010;55:20-7.

17. Lapaire O, Schneider MC, Stotz M, Surbek DV, Holzgreve W, Hoesli IM. Oral misoprostol vs. intravenous oxytocin in reducing blood loss after emergency caesarean delivery. Int J Gynaecol Obstet. 2006;95:2-7.

18. O'Brien P, El-Refaey H, Gordon A, Geary M, Rodeck CH. Rectally administerted misoprostol for the treatment of postpartum haemorrhage unresponsive to oxytocin and ergometrine: a descriptive study. Obstet Gynecol. 1998;92(2):212-4.

19. Khan RU, El-Refaey H. Pharmacokinetics and adverse-effect profile of rectally administered misoprostol in the third stage of labor. Obstet Gynecol. 2003;101:968-74.

20. Zieman M, Fong SK, Benowitz NL, Banskter D, Darney PD. Absorption kinetics of misoprostol with oral and vaginal administration. Obstet Gynecol. 1997;90:88-92.

21. Tang OS, Schweer H, Seyberth HW, Lee SW, Ho PC. Pharmacokinetics of different routes of administration of misoprostol. Hum Reprod. 2002;17:332-6. 